\section{Ondskabens banalitet - nyt lys over Hannah Arendt}

Ondskabens banalitet (redigeret af Carsten Bagge Laustsen og Jacob Dabl Rendtorff), Museum Tusculanum Forlag, 320 sider, $248 \mathrm{kr}$.

Det onde vækker umiddelbart til eftertanke. Er ondskab en dybsindig, dæmonisk kraft, der hjemsøger menneskeslægten, eller er det snarere et overfladefænomen, som ikke stikker særligt dybt? Et nyligt udkommet værk om Hannah Arendt markerer allerede med titlen, Ondskabens banalitet, at det onde synes at høre ind under det sidstnævnte tilfælde. Arendt var af den overbevisning, at det onde i kraft af sit tomme væsen altid runger hult, en tomhed, der med tiden vil tone frem, mens det gode er kendetegnet ved en uudgrundelig dybsindighed, der præcis i disse dybder bevarer det godes væsen. Så snart det gode udsiges, påkaldes eller på anden vis træder frem, så falmer det, og kan oven i købet forvandle sig til ondskab ved at træde manifest frem. Det gode og det onde har et fællestræk, som kan gøre det vanskeligt at holde dem ude fra hinanden i deres fremtrædelse: De tager på radikal vis deres udgangspunkt udenfor det menneskelige fællesskab. Væsentligt set er der imidlertid en verden til forskel: Det onde har ikke grund $i$ andet og mere end sig selv - det er uden grund.

"Vi har svært ved at forstå Eichmann, for der er ikke noget at forstå", lyder en af de mange rammende formuleringer i det foreliggende værk, der kredser omkring de erfaringer, som Arendt gjorde sig i Jerusalem i 1961, da hun overværede forhøret af Adolf Eichmann, der spillede en afgørende rolle i nazisternes jødeudryddelser; men hvilken rolle? Arendts kontroversielle bud, der vakte et ramaskrig i hendes samtid, afdxmoniserer Eichmann, som hun beskriver som en tankeløs og klichéfyldt person, der uden kritisk stillingstagen kun havde sans for ét: at føre den ordre ud i livet, som han i det nazistiske hierarki fik øverst oppe fra. Eichmann var, i Arendts udlægning, blot et tandhjul i den grusomme maskine, som nazisterne havde bygget op i løbet af 30'erne. Under inddragelse af hans livshistorie kan Arendt vise, hvorledes denne ukomplicerede mand igennem en arbejdsom stræben efter anerkendelse, ender med at indtage den centrale plads som ansvarlig for deportationen af jøderne.

De grundigere analyser og hele udvidelsen af konteksten går Ondskabens banalitet efter i sømmene. Redaktørerne Carsten Bagge Laustsen og Jacob Dahl Rendtorff indleder med en tekstnær gengivelse af tankegangen i Arendts værk, Eichmann in Jerusalem, som de tillige yder et kritisk modspil i form af præcist formulerede spørgsmål. Var Eichmann så banal, og grunder det ondes banalitet sig entydigt på tankeløshed? Disse spørgsmål genoptages af flere af bidragyderne, der med så forskellige 
indspil som Kant, Habermas, Adorno, Lacan, Sloterdijk m.fl. i Arendts ånd går kritisk til værks. Redaktørerne slutter selv af med et stærkt essay om erindring og apori, og bidragene kommer i det hele taget godt rundt i hele Arendts forfatterskab, selvom interessen primært samler sig om det politiske landskab med fokus på det onde, totalitarisme, ret, autoritet, moral og ansvar. I sandhed danner disse temaer selve det historiske centralfelt, som den arendt'ske tænkning indskriver sig i, men det er værd at spørge om Arendts enestående udlægning af dette felt låner sit lys et andet sted fra end det politiske selv. Er Arendt "kun" en politisk tænker, eller er der en anden dimension, som kommer til syne i hendes værk?

Ondskabens banalitet angiver allerede $\mathrm{i}$ titlen, at omdrejningspunktet udgøres af Eichmann in Jerusalem, der på fremragende vis belyses fra disse mange forskellige vinkler og udgør en art af grundperspektiv, hvori Arendts andre værker spejles. Med denne indfaldsvinkel indsniger der sig imidlertid en tendens til, at menneskets væsen grunder sig i det politiske fællesskab, og at selve det menneskelige udtømmes i politiske termer. Det følgende er på ingen måde en anke imod bogen, der præcis i sit skarpe sigte kan udgøre en fremragende dialogpartner til at reflektere spændinger i Arendts eget værk.

I bidragene optræder en arendt'sk formulering igen og igen, at totalitarismen overflødiggør mennesket, hvilket varieres over "totalitarismens afhumanisering" (s. 22), "totalitarismen forsøger [...] at lave menneskene og samfundet radikalt om" (s. 32), "forme den menneskelige væren" (s. 33), "reduktion af menneskene" (s. 36), "eliminere muligheden for at tale om menneskene" (s. 61). Helt i forlængelse af Arendt beskrives alt dette som totalitarismens værk, men samtidig optræder andre afhumaniseringsformer som totalitarismens afvikling af enhver form for spontanitet og dens lukning af det åbne, fælles handlingsrum. Også dette er en tro gengivelse af Arendt. Er der imidlertid ikke forskel på mennesket som sådan og så dets mulighed for at handle? Er overflødiggørelsen af mennesket eller elimineringen af enhver tale om mennesker (er det i øvrigt det samme?) det samme som afviklingen af den menneskelige pluralitet, altså det forhold, at totalitarismen nedbryder forskellene imellem menneskene, så de ikke længere skiller sig ud fra hinanden?

Det handler jo om selve den menneskelige væren, som Arendt til tider anskuer aristotelisk, mennesket er et politisk væsen, men som hun til andre tider grunder i en anden ontologi: mennesket er en begyndelse, hvilket hun har fra Augustin. At mennesket er født ind i denne verden, nataliteten, muliggør overhovedet pluralitet, frihed, kort sagt alle de begreber, som den foreliggende bog tager op. Det rejser spørgsmålet: Totalitarismen kan nok nedbryde talen om og rum- 
met for menneskene, så det er umuligt at begynde, men kan den også afvikle selve begyndelsen? Er det overhovedet muligt at slå mennesket som menneske ihjel? Redaktørerne af bogen er inde på, at Arendt præcis anså de mennesker, der til trods for overmagten formår at gøre en ny begyndelse, for at være menneskenes håb og værdighed. Samtidig siger redaktørerne også, at "mennesket gennem diskussion og overvejelse vinder sin værdighed" (s. 36). Jeg tror, at det er rigtigt, at begge tendenser er til stede i Arendts værk, fordi mennesket som begyndelse og dets mulighed for at begynde er knyttet så tæt sammen; men den aristoteliske og den augustinske begyndelseskonception går ikke op i en højere enhed. Hvis mennesket grundlæggende er en begyndelse, så vinder mennesket sin værdighed udenfor det politiske fællesskab, der dog samtidig (!) er med til at bevare menneskets mulighed for at begynde, dvs. dets værdighed.

Vi står ved en bestemt overgang, der ikke kan fikseres, eller rettere er mennesket selve den overgang imellem livet og døden, som udspænder den menneskelige eksistens. Jeg mener ikke, at det er rigtigt, når en af bidragyderne skriver: "For Arendt er det menneskelige altså det menneskeskabte, noget der er resultatet af menneskelig handlen, og som finder sted imellem mennesker." (s. 69) Det er rigtigt, at mennesket "ser ud til" at miste sin menneskelighed, når det står nøgent og ikke er andet end men- neske, og når det er drevet på flugt uden tilhørsforhold til verden, hvorfor det "ser ud til", at det eneste, der kan bevare det menneskelige er indenfor det åbne, politiske fællesskab; men for det første har menneskene ikke suverænt skabt selve muligheden for at handle, hvilket fører hen til det andet, at mennesket ikke har skabt sig selv. Dér forbliver nataliteten, som i den grad ligger en religiøs tydning nær, nedtonet igennem det meste af den foreliggende udgivelse, hvilket kort træder frem i lighedstegnet imellem "den menneskelige pluralitet, den enkeltes evne til at begynde noget nyt og uforudsigeligt." (s. 65) Her er overgangen imellem den nye begyndelse og pluraliteten, imellem menneskets grund og dets politiske fundering allerede foretaget, men det er den overgang, den spænding, som holdes åbent i Arendts værk. Det er rigtigt, at både den enkeltes evne til at begynde og den menneskelige pluralitet er karakteriseret ved spontanitet og uforudsigelighed, men de er ikke lig hinanden. Den åbning, der er til stede i Arendts værk, er, at mennesket ikke fra grunden af er politisk, men også står ind $i$ et andet lys, hvor guderne melder deres ankomst.

Det, der gør, at mennesket ikke blot er et arbejdende og fremstillende væsen, men kan gøre en egen begyndelse, er den enestående hændelse, at det er kommet ind i verden. Mennesket går ikke op i verden, men kommer fra de dybder, hvor det gode holder til. Den grund fjerner menne- 
sket sig imidlertid hele tiden fra, men det er samtidig den eneste grund til, at der fortsat er håb om bedre tider. Hvis alt, der er til, er historie, verden, politik, så ville der ikke være nogen forskel på det gode og det onde. Vinder mennesket sit urørlige væsen ved at blive anerkendt som en moralsk, juridisk person, eller forudsætter menneskets urørlighed, som totalitarismen bringer i fare, ikke en helt anden og anderledes grund?

Det er ikke kun Augustin, som hun lader sig inspirere af, men den måde, hvorpå de homeriske krigere mødes og deles omkring en midte, der er indrømmet af guderne, danner forbillede for det hun kalder "the space of appearance" eller "the in-between". Arendt uddyber rigtignok aldrig de metafysiske højder, der åbner sig under den homeriske himmel og i de augustinske afgrunde $i$ sjælen, men er det ikke den baggrund, der kaster lys over ethvert menneskeligt møde, hvor ud af springer venskab og kærlighed, ansvar, tilgivelse og håb. Når Arendt taler om menneskets værdighed og ret til rettigheder tænker hun det så rent verdsligt? Ja, vi er vendt tilbage til spørgsmålet, som præcis må forblive et spørgsmål - "for begyndelsen er også en gud, der opholdende sig iblandt menneskene redder alt". Hermed anbefales det at påbegynde læsningen af Ondskabens banalitet, der i sandhed kaster nyt lys over Hannah Arendts tænkning.

Jonas Holst Sorensen

\section{Dannelse i Århus}

Dannelse (red. Martin Blok Johansen), Aarbus Universitetsforlag, s.348, 298 kr.

1. Dannelse hedder en antologi, hvis bidragydere alle er ansat ved Aarhus Universitet. Og det er det særlige ved bogen. Bogen er dermed med til at 'bench-marke' Aarhus Universitetet på markedet. Den er et stykke videnudveksling. Og det er et flot initiativ, som en studerende, Martin Blok Johansen, har taget. Det skal han roses for.

Det var Bertel Haarder, som i begyndelsen af 1980'erne gjorde det muligt - igen - at tale om almendannelse. Før den tid blev dannelse altid identificeret med det borgerlige. Og denne identifikation dukker op flere gange $i$ antologien.

Senere blev ordet dannelse erstattet af kultur; der igen blev afløst af værdi, der igen blev afløst af kompetence, der igen blev afløst af videnudveksling. Denne bog behandler alle disse begreber på nær det sidste nye.

I det 19. århundrede og ind $i \mathrm{det}$ 20. var universitetet et statsligt dannelsesuniversitet, som producerede dannelse og sendte dannede mænd ud i landet for at udbrede den til et folk uden dannelse. Dannelse var en kombination af fornuft og rødder; det franske og det tyske; civilisation og kultur eller, som det ofte hedder i bogen her: Uddannelse og dannelse.

Den nye universitetslov forsøger, skønt tiden er til forandring, at 